\title{
Members of the WRKY gene family are upregulated in Canary palms attacked by Red Palm Weevil
}

\author{
Gabriella Lo Verde $^{1} \cdot$ Veronica Fileccia $^{1} \cdot$ Paolo Lo Bue ${ }^{1} \cdot$ Ezio Peri $^{1} \cdot$ Stefano Colazza $^{1} \cdot$ Federico Martinelli ${ }^{1}$ (I)
}

Received: 4 January 2018 / Accepted: 21 October 2018 / Published online: 14 November 2018

(c) Springer Nature B.V. 2018

\begin{abstract}
The Red Palm Weevil (RPW), Rhynchophorus ferrugineus, is one of the major pests affecting several palm species all around the world. The aim of this work was to identify palm genes that are responsive to RPW infestations as a valuable diagnostic tool to detect the insect attack. We have analysed a total of 15 genes that were divided in two subsets: (1) 7 genes previously linked with RPW attacks, but not involved in biotic stress responses, and (2) 8 genes encoding members of the WRKY family, a class of transcription factors well-known to be linked with both abiotic and biotic stress responses. The analysis was conducted on 4-year-old Canary palms comparing uninfested plants and infested plants at 30 and 45 days after RPW oviposition. Principal component analysis of gene expression data showed that the overall analysis of WRKYs partially distinguished the three groups of plants. No separation of the three groups was observed when PCA was conducted using genes that were not linked with biotic stress responses. Among the 8 analysed WRKYs, 4 genes (WRKY2, WRKY28, WRKY14, WRKY51) were significantly induced by RPW attacks at 45 days after the beginning of the infestation. These four WRKYs could be further investigated to confirm if they may be used to help diagnosis of RPW infestations in palm.
\end{abstract}

Keywords Palm $\cdot$ Phoenix canariensis Hort. ex Chabaud $\cdot$ Rhynchophorus ferrugineus $\cdot$ WRKYs

\section{Introduction}

The Red Palm Weevil (RPW), Rhynchophorus ferrugineus (Olivier) (Coleoptera: Curculionidae), is native to southern Asia and Melanesia, but in the last three decades it has spread worldwide mainly due to the movement of infested planting materials (Dembilio and Jaques 2015; Rochat et al. 2017). RPW is one of the more dangerous insect pests of palm trees (Arecaceae), of which about 40 species have been reported as hosts (Rochat et al. 2017).

In the Mediterranean Basin, the RPW was recorded mainly on Canary Islands date palms, a species different

Handling Editor: Heikki Hokkanen.

Electronic supplementary material The online version of this article (https://doi.org/10.1007/s11829-018-9653-6) contains supplementary material, which is available to authorized users.

Federico Martinelli

federico.martinelli@unipa.it

1 Universita degli studi di Palermo, Dipartimento di Scienze Agrarie Alimentari e Forestali, Viale delle Scienze, 90128 Palermo, Italy from those infested in its native areas. This insect is currently considered the most dangerous pest of this palm species such as Phoenix canariensis Hort. ex Chabaud (Arecaceae). This palm species is a native of the Canary Islands that is typically cultivated in the Mediterranean basin, where it is the most important ornamental palm, and also in Australia and the southeastern United States where wet-summer or humid subtropical climates are present.

The damage is due to larvae, which feed and develop inside the palm stipe, destroying the vascular system and the only apical bud of the plant (Kontodimas et al. 2017). The main symptoms indicating the infestation on Canary palms consist in the occurrence of perforations in the crown, where the digested fibres from larvae are ejected; heavily infested palms show dried offshoots causing the crown loss and the presence of fallen empty pupal cases and dead adults at their base (Dembilio and Jaques 2015; Kontodimas et al. 2017). Only at advanced stages of the infestation the injury symptoms become evident, in some cases even some months after infestation (Pasini and Rumine 2014), but heavy infestations are difficult to manage because the immature stages are protected within the palm stipe, and attacked palms usually die (Kontodimas et al. 2017). 
Since RPW detection in Europe, many studies have been carried out to develop effective control methods: chemical, biological, biotechnological and mechanical (Guarino et al. 2011, 2013, 2015; Lo Verde et al. 2011, 2014; Francesca et al. 2014; Vacas et al. 2017). At the present time, control strategies based exclusively on biological control are not considered effective, and the use of chemicals is essential, also in urban areas, where infestations mainly occur (Suma et al. 2017).

The early identification of RPW infestations is a real problem in the management of this pest, as in many cases their diagnosis is possible when plants are already almost destroyed by larvae (Soroker et al. 2017). Currently, detection of infested palms in Canary palms is done visually and largely depends on the detection skills and experience of the staff involved (Suma et al. 2017).

Until now, different methods have been experienced to identify early signs of infestations, such as the use of bioacoustics sensors (Martínez-Rach et al. 2013). Chemical sensors have been tried to analyse early volatiles produced by RPW-attacked trees using trained dogs (Nakash et al. 2000; Suma et al. 2013). However, these induced volatiles do not have high specificity and sensitivity. A transcriptome profiling at two symptomatic stages has been conducted with Next-Generation Sequencing (NGS) to elucidate early and late mechanisms of symptoms progression, and to identify early host biomarkers that may be used to help diagnosis of the RPW infestations (Giovino et al. 2015). This approach was shown to be effective in identifying possible candidate to improve detection of diseases in crops (Martinelli et al. 2016). These methods are based on a deep analysis of gene regulatory networks through an integrated approach of functional genomic data mining techniques (Dandekar et al. 2010). They may be well-performed in palm species since the genome has been recently sequenced (Al-Dous et al. 2011; Al-Mssallem et al. 2013).

An important goal for the RPW management will be the identification of RPW-regulated genes associated with the symptomatology in order to analyse them with both lab or infield instruments. Previous transcriptomic and metabolomic analysis highlighted the upregulation of pathways linked with biotic stress response as well as the early induction of some members of WRKY transcription factors (Giovino et al. 2015, 2016).

The present research was carried out to evaluate the relationship between the RPW infestation and the expression of previous identified and well-known biotic stressregulated genes. The aim was to determine (1) how a subset of host genes is modulated by RPW infestations, (2) if the analysis of their expression may be used to discriminate healthy and RPW-infested palms.

\section{Materials and methods}

\section{Insects}

RPW adults used to infest the plants were collected by pheromone-baited traps (Picusan ${ }^{\circledR}$, Sansan Prodesing SL, Náquera, Valencia, Spain) located in Parco d'Orleans, Department of Agricultural, Food and Forestry Sciences (University of Palermo, Italy). The insects were collected 1-7 days before the plant infestation, kept in group of 10-15 individuals of both sexes in plastic cages $(20 \times 40 \times 15 \mathrm{~cm})$ with two 5-cm-diameter mesh-covered holes, under laboratory conditions $\left(27 \pm 2{ }^{\circ} \mathrm{C}, 16: 8\right.$ photoperiod and $\left.60 \% \mathrm{RU}\right)$, and fed with apples cv. Golden delicious, until their use for experiments.

\section{Plant rearing and infestation}

The experiments were carried out using 15 P. canariensis reared in pots of $30 \mathrm{~cm}$ in diameter and about $0.03 \mathrm{~m}^{3}$ in the greenhouse of the Department of Agricultural, Food and Forest Sciences (University of Palermo). All plants were 4 years old, $180 \mathrm{~cm}$ in height, including leaves, and $15 \mathrm{~cm}$ in trunk diameter, at their base. The plants were carefully screened for the presence of RPW. Then, asymptomatic plants were singly isolated in an anti-aphid net sleeve, irrigated every 3 days and kept under field conditions for 30 days, from $20 / 06 / 2016$ to $20 / 07 / 2016$, at a mean daily temperature of $29.3 \pm 2.9^{\circ} \mathrm{C}$ in order to certify that RPW infestation did not occur.

Then, 6 plants were infested by releasing inside each sleeve 4 RPW adults ( 3 females and 1 male), and 9 were left uninfested to be used as control. After 7 days, the insects were removed. All plants were maintained at the same conditions described above. Thirty and forty-five days after infestation (T mean $30.1 \pm 2.8^{\circ} \mathrm{C}$ and $30.0 \pm 2.6{ }^{\circ} \mathrm{C}$, respectively), the plants were inspected in order to observe the development of infestation by recording the occurrence of visual symptoms, such as, for example, presence of oviposition holes in the basal portion of leaves, tips of the leaves dried out, central leaves dried and collapsed. After plant material sampling, infested plants, 3 for each interval, were cut and dissected, and the vegetal material and the potted soil were examined in order to observe possible RPW individuals.

\section{Plant material}

Three plant conditions were compared: uninfested (3 groups each of 3 plants sampled, respectively, at the infestation date, after 30 and 45 days), infested after 30 days ( 3 plants), and 
infested after 45 days ( 3 plants). Three biological replicates were analysed for each of the three conditions. Each biological replicate consisted in 5 leaflets, gently cut by fine scissor from three leaves of the same plant (approximately $1 \mathrm{~g}$ ). Samples were immediately frozen in liquid nitrogen and then stored at $-80^{\circ} \mathrm{C}$ until used for the analysis.

\section{RNA extraction}

The total RNA was extracted from $1 \mathrm{~g}$ of tissue of each biological replicate using the TRI Reagent ${ }^{\circledR}$ Protocol (Sigma-Aldrich, St. Louis, MO, USA). The RNA concentrations were obtained using a NanoDrop ND-1000 spectrophotometer (NanoDrop Technologies, Wilmington, DE, USA). The RNA quality and purity were determined by an Agilent Bioanalyzer (Folsom, CA, USA).

\section{Gene expression analysis}

Expression pattern of the 15 genes did not significantly change among uninfested plants during the 45 days of the experiment so for this category, an average of three measurements was considered. Each time point of the uninfested category was analysed using 3 biological replicates for a total of 9 replicates. Fifteen genes were analysed using qRTPCR. They belonged to two categories: not involved in biotic stress ( 7 genes) and encoding WRKY members typically involved in biotic stresses ( 8 genes). Primers were designed basing on each target sequence using the freely available primer3 software (Table S1). Retrotranscription reactions were conducted using the Quantitect Reverse Transcription Kit (Qiagen) instructions. A standard curve was produced for each gene to determine primer specificity. Amplifications were performed using $20 \mathrm{ng}$ cDNA in a $15 \mu \mathrm{L}$ final volume using a Biorad iQ5 PCR system (Biorad) under these amplification conditions: $10 \mathrm{~min}$ at $95{ }^{\circ} \mathrm{C} ; 40$ cycles of $15 \mathrm{~s}$ at $95{ }^{\circ} \mathrm{C}$; and $1 \mathrm{~min}$ at $60^{\circ} \mathrm{C}$. Fluorescent signals were analysed during the annealing step and $\mathrm{C}_{\mathrm{T}}$ values were determined following baseline subtraction. 18S (AF206991.1) was used as an endogenous reference and $\Delta \Delta \mathrm{C}_{\mathrm{T}}$ was obtained by subtracting the average of $18 \mathrm{~S}$ from the average $\mathrm{C}_{\mathrm{T}}$ of the analysed gene. The reference gene was tested on the 9 analysed samples and it showed similar level of transcript abundance.

\section{Statistical analysis}

Analysis of variance (GLM) was performed according to the experimental design. Post-hoc tests were performed using Tukey's significant difference (HSD 0.05) at the 5\% probability level. Principal component analysis (PCA) was performed after calculating with the $\Delta \Delta \mathrm{C}_{\mathrm{T}}$ the relative expression values for each gene to the reference gene (18S) for each of the biological replicates of the three plant categories. SAS
Institute software (2008) was used to perform all statistical analyses.

\section{Results}

\section{Plant infestation}

Occurrence of oviposition holes in all infested plants was clearly observed at the first observation date, 30 days after infestation. Moreover, one of the three plants that were used for sampling and dissected 30 days after infestation, showed also a clear change in the slope of central leaves. At this date, a total of 18 RPW larvae (4, 4, and 10 larvae inside each palm, respectively) and 1 cocoon containing a mature larva were found inside the three sampled plants. The maximum number of larvae was found in the palm with the sloped central leaves.

Forty-five days after infestation, all three infested palms showed a change in the slope of central leaves. Only 2 larvae were found inside two plants, whereas 19 cocoons (4, 6 and 9 per plant, respectively), all of which containing pupae, were recorded. At this date, plants were almost completely damaged, and all RPW instars were found in the basal part of the plants and inside the soil in the rearing pots.

\section{Gene expression analysis}

PCA was performed considering the two categories of genes listed above. Regarding the first category of genes, the two principal components $\mathrm{PC} 1$ and $\mathrm{PC} 2$, respectively, explained $36 \%$ and $32 \%$ of the total variability (Fig. 1). However, no

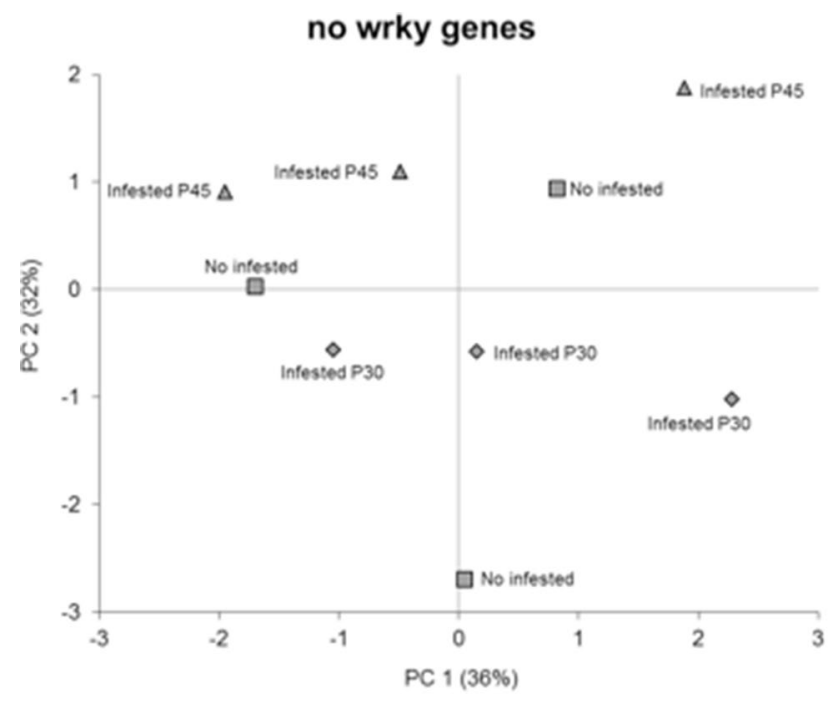

Fig. 1 PCA 1. Principal component analysis of gene expression data not specifically involved in biotic stresses. Percentage of total variability was indicated for each principal components 


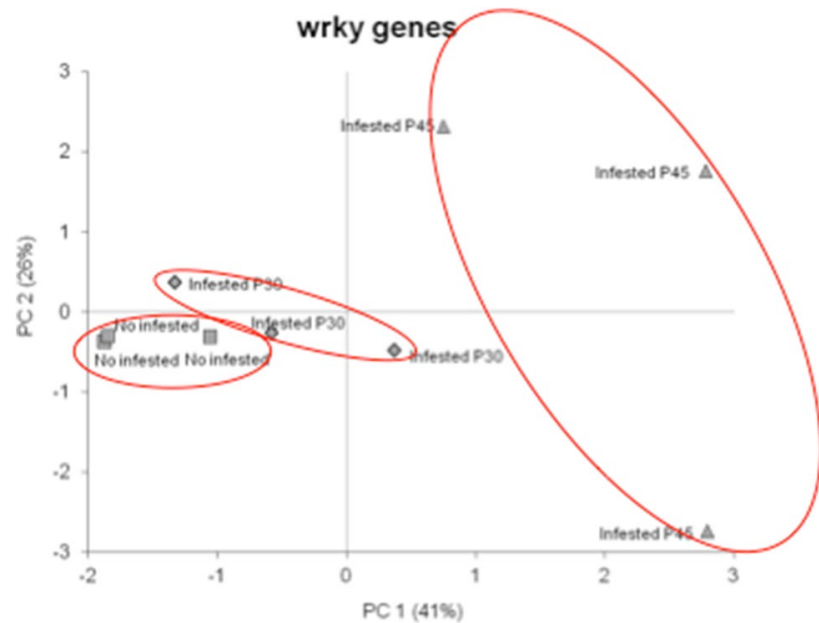

Fig. 2 PCA 2. Principal component analysis of expression data of 8 WRKY genes

clear separation was observed between the three different plant conditions (uninfested, infested after 30 and 45 days). Considering the category of WRKY genes, PC1 and PC2 explained, respectively, $41 \%$ and $26 \%$ of the data variability
(Fig. 2). A better separation of the three plant conditions was observed. Particularly PC2 separated uninfested plants from infested after 30 days. PC1 mostly contributed to distinction between infested at 45 days from the other two groups. Among the 7 non-biotic stress categories, no genes were significantly regulated by RPW neither at 30 days nor 45 days after infestation (Table 1). Among the 8 analysed WRKYs, no genes were modulated by RPW infestation at 30 days after infestation. WRKY2, WRKY28, WRKY14, WRKY51 were significantly induced in plants subjected to 45 days of infestation in comparison to uninfested plants (Table 2).

\section{Discussion}

The rationale of this work was to determine if a subset of host RPW-regulated genes identified in a previous study (Giovino et al. 2015) was able to effectively help in the detection and confirmation of symptomatology of RPW infestation in Phoenix canariensis Hort. ex Chabaud. We aimed at dividing the genes in two groups: (1) genes encoding transcription factors modulating plant responses to biotic stresses, (2) previously identified RPW-regulated genes not

Table 1 ANOVA analysis of expression data of a subset of genes involved in pathways not involved in biotic stress responses

\begin{tabular}{lllll}
\hline Gene & $P$ value & Uninfested & Infested after 30 days & Infested after 45 days \\
\hline Alpha-amylase-like & 0.27 & $0.70 \pm 0.58 \mathrm{a}$ & $0.30 \pm 0.17 \mathrm{a}$ & $0.58 \pm 0.52 \mathrm{a}$ \\
UDP-Glycosyltransferase & 0.21 & $0.08 \pm 0.008 \mathrm{a}$ & $0.22 \pm 0.34 \mathrm{a}$ & $0.41 \pm 0.51 \mathrm{a}$ \\
Laccase7 & 0.20 & $0.00007 \pm 0.0001 \mathrm{a}$ & $0.009 \pm 0.01 \mathrm{a}$ & $0.14 \pm 0.13 \mathrm{a}$ \\
Glycerol-3-phosphate Acyltransferase 3 & 0.55 & $1.25 \pm 1.04 \mathrm{a}$ & $1.24 \pm 1.24 \mathrm{a}$ & $0.83 \pm 0.15 \mathrm{a}$ \\
Uridine diphosphate Glycosyltransferase 74E2 & 0.82 & $0.94 \pm 0.88 \mathrm{a}$ & $1.41 \pm 1.32 \mathrm{a}$ & $0.43 \pm 0.39 \mathrm{a}$ \\
Glycosyl hydrolases family 32 protein & 0.64 & $1.20 \pm 0.82 \mathrm{a}$ & $0.59 \pm 0.51 \mathrm{a}$ & $0.41 \pm 0.09 \mathrm{a}$ \\
Peptidase M20/M25/M40 family protein & 0.85 & $0.12 \pm 0.05 \mathrm{a}$ & $0.28 \pm 0.22 \mathrm{a}$ & $0.33 \pm 0.30 \mathrm{a}$ \\
\hline
\end{tabular}

The choice of these genes was based on the previous transcriptomic analysis conducted by Giovino et al. (2015). Relative quantification analysis using qRT-PCR was performed based on $\Delta \Delta \mathrm{C}_{\mathrm{T}}$ and using 18S (AF206991.1) as an endogenous reference. Data were shown for the three plant categories: uninfested, 30 days and 45 days after infestation. Different letters mean significant differences after post-hoc test. Means and standard deviations were shown

Table 2 ANOVA analysis of expression data of a subset of genes encoding WRKY transcription factors

\begin{tabular}{lllll}
\hline Gene & $P$ value & Uninfested & Infested after 30 days & Infested after 45 days \\
\hline WRKY 2 & 0.03 & $1.88 \pm 0.67 \mathrm{~B}$ & $4.81 \pm 5.55 \mathrm{~B}$ & $17.30 \pm 4.59 \mathrm{~A}$ \\
WRKY 9 & 0.82 & $0.99 \pm 1.00 \mathrm{~A}$ & $0.37 \pm 0.35 \mathrm{~A}$ & $0.61 \pm 0.81 \mathrm{~A}$ \\
WRKY 28 & 0.05 & $0.17 \pm 0.11 \mathrm{~B}$ & $0.03 \pm 0.01 \mathrm{~B}$ & $1.36 \pm 0.67 \mathrm{~A}$ \\
WRKY 14 & 0.02 & $0.00 \pm 0.00 \mathrm{~B}$ & $2.90 \pm 3.35 \mathrm{~B}$ & $43.33 \pm 18.43 \mathrm{~A}$ \\
WRKY 47 & 0.78 & $1.82 \pm 3.14 \mathrm{~A}$ & $15.00 \pm 12.29 \mathrm{~A}$ & $8.59 \pm 13.16 \mathrm{~A}$ \\
WRKY 51 & 0.05 & $0.00 \pm 0.00 \mathrm{~B}$ & $0.00 \pm 0.00 \mathrm{~B}$ & $14.32 \pm 7.33 \mathrm{~A}$ \\
WRKY 40 & 0.87 & $0.06 \pm 0.06 \mathrm{~A}$ & $0.24 \pm 0.34 \mathrm{~A}$ & $0.33 \pm 0.37 \mathrm{~A}$ \\
WRKY 75 & 0.28 & $0.01 \pm 0.02 \mathrm{~A}$ & $0.23 \pm 0.28 \mathrm{~A}$ & $0.34 \pm 0.57 \mathrm{~A}$ \\
\hline
\end{tabular}

WRKY genes were selected based on previous RNA-seq data obtained by Giovino et al. (2015) and based on their well-known role in biotic stress responses. qRT-PCR Data were obtained using the $\Delta \Delta \mathrm{C}_{\mathrm{T}}$ method as previously described. Different letters mean significant differences after post-hoc test. Means and standard deviations were shown 
strictly associated with biotic stress responses. This latter group was used as a reference in order to highlight the capability of biotic stress-related genes to identify RPW infestations.

Alpha-amylase is involved in the degradation of starch to produce glucose-1-phosphate. This gene was shown to be somewhat significantly affected by biotic stresses such as Huanglongbing disease in Citrus (Martinelli et al. 2016). Transcriptomic analysis conducted in Citrus in response to "Candidatus Liberibacter asiaticus" supported the hypothesis that this gene is linked to disorders in sugar partitioning. This gene was shown to be induced by RPW attacks at late stage of infestation in palm (Giovino et al. 2015). Our data do not confirm the modulation of this gene in response to RPW. Here, we observed no significant regulation of this gene in both samples collected 30 and 45 days after infestation, respectively. Considering that this gene is not just enhanced by biotic stress, this contrasting evidence was expected. These opposite findings may be due to environmental and genetic variability and to differences on developmental stages of infested plants, as our experiment was conducted with young plants that were severely attacked after 30 days while Giovino et al. (2015) analysed older plants at different infestation stages.

Glycosyltransferase catalyse the transfer of sugars to different acceptor molecules. These enzymes are categorized into families based on the sequence similarity, catalytic specificity and the presence of consensus sequences (Ross et al. 2001). UDP-glycosyltransferase gene was induced at late disease according to previous published data (Giovino et al. 2015). This family of enzymes is well known to be responsible of glycosylation of a range of aglycones, such as plant hormones, plant secondary metabolites and xenobiotic compounds (Vogt and Jones 2000). Glycosylation modulates the function of the aglycones, such as their bioactivity, their solubility and their transport activities inside cells and plants.

Laccases are enzymes playing a key role in the polymerization of lignin precursors. The genes encode a large group of enzymes belonging to multicopper enzymes, such as ascorbic acid oxidase and ceruloplasmin (Mayer and Staples 2002). Laccase is one of the oldest studied enzymes since it has been characterized as a metal containing oxidase by Bertrand (1985). Laccase7 was observed to be induced at early RPW infestation (Giovino et al. 2015) while in this work it was upregulated only after 45 days after infestation. These differences are probably linked to different environmental, genetic, developmental conditions between the two experiments as it occurred for the other two genes previously discussed.

Glycerolipid metabolism was shown be upregulated by RPW in field conditions (Giovino et al. 2015). However, this was not confirmed in the present study: glycerol-3-phosphate acyltransferase 3 was not affected by RPW neither at 30 days nor at 45 days after infestation. No RPW regulation was observed for uridine diphosphate glycosyltransferase 74E2 and glycosyl hydrolases in the present study. Peptidases are divided into two groups of enzymes: the endopeptidases which degrade the interior of peptide chains while the exopeptidases cleave peptide bonds at the end of peptide molecules (Barrett 1994). Most of the peptidases in plants are cysteine proteinases belonging to caspases, calpains, ubiquitin C-terminal hydrolases and ubiquitin-specific proteinases belonging to the ubiquitin-proteasome-dependent pathway that catalyse deubiquitination of proteins (Vierstra 2003). The analysis of the 7 genes previously found to be RPW-regulated, did not confirm their link to RPW attacks as previously found in open filed conditions (Giovino et al. 2015). This was not surprising, considering that these genes are modulated by a variety of environmental stress conditions, both abiotic and biotic. The PCA analysis confirmed that these genes could not be considered as good markers to improve detection of RPW infestations in palm.

WRKY proteins are a well-known category of sequencespecific DNA-binding transcription factors (Rushton et al. 2010). These stress-related proteins took the name from a highly conserved WRKY domain, which includes the almost invariant WRKYGQK sequence at the $\mathrm{N}$-terminus followed by a zinc-finger motif (Rushton et al. 2010). Jones and Dangl (2006) demonstrated that WRKYs play important roles in parts of plant innate immune responses (PAMP-triggered immunity and effector-triggered immunity). In Arabidopsis, $70 \%$ of WRKYs are responsive to pathogen attacks and salicylic acid treatment (Dong et al. 2003). This role has been confirmed by many studies conducted in knockout mutants of these genes (Chen and Chen 2000). However, a regulation of these genes has been observed not only at transcriptional level but also at post-translational and proteins levels such as cellular localization through the recognition of the W-box motif (de Pater et al. 1996).

Among the analysed WRKYs, we observed an upregulation of WRKY51, WRKY2, WRKY14 and WRKY28 after 45 days of infestation. WRKY51 was shown to be upregulated by RPW in field conditions (Giovino et al. 2015). Our work confirmed that WRKY51 might be linked with response to RPW although at late symptomatic stage. Recently, a novel JAV1-JAZ8-WRKY51 (JJW) complex showed to control jasmonic acid (JA) biosynthesis in the response to insect attack. In healthy plants, this complex inhibits JA biosynthesis to maintain it at low levels and to allow allocation of plant energies for growing. When plants are attacked by insects, calcium influxes are quickly triggered to induce calmodulin-dependent phosphorylation of JAV1, which eliminates JJW complex and induces JA biosynthesis, provoking a rapid burst of JA for plant defensive measures (Yan et al. 2018). Gao et al. (2011) showed that WRKY51 is 
involved in inducing SA-mediated responses and repressing JA-inducible defences, resulting in enhanced resistance to biotrophic plant pathogens but causing enhanced susceptibility to necrotrophic plant pathogens. Considering that RPW should induce JA-mediated responses, we may speculate that the induction of this gene may not be beneficial for the infested plant. WRKY51 was shown to interact with WRKY50 repressing JA-responsive gene PDF1.2 (Spoel et al. 2003). This is another clue that the upregulation of this gene may not be beneficial to actively respond to RPW infestations. In addition to this role, WRKY51 has been shown to interact with WRKY71 and play an important role in the $\mathrm{ABA}$ and GA signalling crosstalk in aleurone cells (Xie et al. 2006). Interestingly, GA promotes the degradation of OsWRKY71 (but not OsWRKY51) causing seed germination (Zhang et al. 2004).

WRKY2 is a WRKY transcription factor that has been isolated in grape and with a high sequence similarity of WRKY proteins (Mzid et al. 2007). This protein seems to play an important role in defence, considering that the over-expression of this gene in tobacco plants induced an enhanced tolerance to necrotrophic fungi. The role of this WRKY factor is not clear although it may be linked with differences in xylem ring width (Guillaumie et al. 2010). These modifications implied that this gene may be involved in lignification and xylem formation as shown by the expression observed specifically in sclerenchyma and xylem undergoing lignification. Transgenic plants with increased expression of WRKY2 showed an upregulation of genes involved in lignin biosynthesis or cell wall formation (Guillaumie et al. 2010).

WRKY14 is a key transcription factor that plays an important role in modulating Trp and Trp-derived secondary metabolites (Kang et al. 2011). WRKY14 was shown to interact with the W-box elements of genes important for Trp and serotonin biosynthesis. This transcription factor was showed to be suppressed by cytokinin treatment and upregulated by $\mathrm{ABA}$. ABA signalling has been linked to the repression of SAR and the induction of JA signalling (Martinelli et al. 2013). Since JA-related responses are typically associated with necrotroph responses, we may hypothesize that the induction of this gene may beneficially promote defensive palm response to the insect. This gene was significantly induced by RPW only at 45 days after infestations of RPW and resulted also upregulated at symptomatic stage in field trees infected by RPW (Giovino et al. 2015). Indeed, WRKY14 was considered a key gene among the subset of genes linked with RPW symptomatology. Based on these evidences, we may suppose that the induction of this gene may serve for the biosynthesis of secondary metabolites produced as a response to RPW attacks.

Chen et al. (2013) showed that the oxidative burst in transgenic lines overexpressing WRKY28 was higher that in wild-type in response to Sclerotina sclerotiorum infection.
Upregulation of WRKY28 showed to induce resistance to $S$. sclerotiorum infection in Arabidopsis thaliana and this was probably due to the enhanced reactive oxygen species (ROS) production that relieves its block on oxidative burst and allows to counteract the toxicity to oxalic acid and pathogen invasion at early stages (Chen et al. 2013). It is well accepted that early production of ROS represses pathogen invasion enhancing cell wall glycoproteins or directly eliminating the pathogen promoting further defenses. In addition, $\mathrm{Wu}$ et al. (2011) showed that induction of WRKY28 increased plant resistance to Botrytis cinerea. WRKY28 was shown to be positive regulator of JA/ET-mediated plant defensive responses against $B$. cinerea infection. Recent works showed that WRKY28 is a key player in biotic stress responses since it negatively regulates defensive responses against rice blast strain Ina86-137 (Chujo et al. 2013).

In our study, gene expression analysis showed that 4 of the 8 WRKY genes were significantly upregulated at 45 days after infestation comparing with uninfested plants. Although transcript changes were not significant at 30 days after infestation, a trend of upregulation was observed for WRKY2, WRKY47, WRKY40 and WRKY75. Each of these gene could not be considered as single specific biomarkers for the RPW infestation in P. canariensis, nevertheless the expression of all together was effective to distinguish the three plant groups. Indeed, PCA results clearly showed that WRKY expression data were able to discriminate the three palm groups while the other 7 genes previously found by Giovino et al (2015) did not show a clear expression pattern linked with RPW infestations. The typical symptoms of RPW attacks were observed even at 30 days after infestation. It is worthy to notice that the number of adults used for the experiment was high and this lead to the presence of a high level of ovipositions causing the development of a high number of larvae and a great level of infestation. Indeed, the identification of RPW infestations at this time might be already at middle symptomatic stage. However, the analysis of these key genes might be still useful since the symptoms were not clear and could not be clearly associated to RPW infestations. It will be essential to analyse the expression of these WRKY genes at earlier stage (15 days after infestation) or using a lower number of adults in order to determine if the overall analysis using PCA will be still able to separate uninfested from infested plants. This will be the object of a next future experiment. The high variability observed in transcript abundance at the first infestation stage might be due to the use of palms with slight differences in age and location of mother plants.

In conclusion, the results presented here showed that analysis of a small subset of WRKY genes involved in biotic responses allows distinguishing RPW attack at 45 days after infestations. However, it is worthy to notice that only four WRKYs among the eight members analysed 
were significantly induced by RPW. The role of these four WRKYs needs to be further investigated in relation to palm responses to RPW attacks. Since in our experimental conditions the four WRKYs were detected when palms were already seriously damaged, further extensive analysis need to be conducted on palms of different age and with different infestation level in field conditions in order to determine if these genes may be used as biomarkers to improve detection of RPW attacks. It is highly desirable that RNA-seq analysis will be conducted immediately after oviposition of RPW adults in controlled conditions in order to identify specific biomarkers at earlier asymptomatic stages. For these analyses, tissues close to the oviposition sites should be used. The untargeted transcriptomic approach will allow to identify candidate host biomarkers that should be validated with qRT-PCR in controlled conditions. Identification of a pool of biotic stress-related genes could be useful to set up portable instruments such as chips, lateral flow microarrays or LAMP-based machines, able to carry out the amplification of 5-10 DNA target sequences with a simple rapid procedure and a cost of few euro per reaction, with the aim of improve the protocols of early plant pathogen detection. Considering also that a high variability was observed on gene expression data, utilizing such portable instruments could allow to process in a short time and with low costs an enhanced number of biological replicates, in order to clearly distinguish possibly infested plants from healthy ones.

Acknowledgements The authors wish to thank the Servizio Informativo Agrometeorologico Siciliano-SIAS—of the Sicilian Region for providing temperature data.

\section{References}

Al-Dous EK, George B, Al-Mahmoud ME, Al-Jaber MY, Wang H, Salameh YM, Al-Azwani EK, Chaluvadi S, Pontaroli AC, DeBarry J, Arondel V, Ohlrogge J, Saie IJ, Suliman-Elmeer KM, Bennetzen JL, Kruegger RR, Malek JA (2011) De novo genome sequencing and comparative genomics of date palm (Phoenix dactylifera). Nat Biotechnol 29:521-527. https://doi.org/10.1038/ nbt. 1860

Al-Mssallem IS, Hu S, Zhang X, Lin Q, Liu W, Tan J, Yu X, Liu J, Pan L, Zhang T, Yin Y, Xin C, Wu H, Zhang G, Ba Abdullah MM, Huang D, Fang Y, Alnakhli YO, Jia S, Yin A, Alhuzimi EM, Alsaihati BA, Al-Owayyed SA, Zhao D, Zhang S, Al-Otaibi NA, Sun G, Majrashi MA, Li F, Tala Wang J, Yun Q, Alnassar NA, Wang L, Yang M, Al-Jelaify RF, Liu K, Gao S, Chen K, Alkhaldi SF, Liu G, Zhang M, Guo H, Yu J (2013) Genome sequence of the date palm Phoenix dactylifera L. Nat Commun 4:2274. https ://doi.org/10.1038/ncomms3274

Barrett AJ (1994) Classification of peptidases. Methods Enzymol 244:1-15. https://doi.org/10.1016/0076-6879(94)44003-4

Bertrand G (1985) Sur la laccase et sur le pouvoir oxydant de cette diastase. CR Acad Sci Paris; 120:266-269

Chen C, Chen Z (2000) Isolation and characterization of two pathogenand salicylic acid-induced genes encoding WRKY DNA-binding proteins from tobacco. Plant Mol Biol 42:387-396. https://doi. org/10.1023/A:1006399311615

Chen X, Liu J, Lin G, Wang A, Wang Z, Lu G (2013) Overexpression of AtWRKY28 and AtWRKY75 in Arabidopsis enhances resistance to oxalic acid and Sclerotinia sclerotiorum. Plant Cell Rep 32(10):1589-1599. https://doi.org/10.1007/s00299-013-1469-3

Chujo T, Miyamoto K, Shimogawa T, Shimizu T, Otake Y, Yokotani N, Nishizawa Y, Shibuya N, Nojiri H, Yamane H, Minami E, Okada K (2013) OsWRKY28, a PAMP-responsive transrepressor, negatively regulates innate immune responses in rice against rice blast fungus. Plant Mol Biol 82(1-2):23-37. https://doi.org/10.1007/ s11103-013-0032-5

Dandekar AM, Martinelli F, Davis CE, Bhushan A, Zhao W, Fiehn O, Skogerson K, Wohlgemuth G, D'Souza R, Roy S, Reagan RL, Lin D, Cary RB, Pardington P, Gupta G (2010) Analysis of early host responses for asymptomatic disease detection and management of specialty crops. Crit Rev Immunol 30:277-289. https:// doi.org/10.1615/CritRevImmunol.v30.i3.50

de Pater S, Greco V, Pham K, Memelink J, Kijne J (1996) Characterization of a zinc-dependent transcriptional activator from Arabidopsis. Nucleic Acids Res 24:4624-4631

Dembilio Ó, Jaques J (2015) A Biology and management of red palm weevil. In: Wakil W, Romeno Faleiro J, Miller ThA (eds) sustainable pest management in date palm: current status and emerging challenges. Springer, New York, pp 13-36

Dong J, Chen C, Chen Z (2003) Expression profiles of the Arabidopsis WRKY gene superfamily during plant defense response. Plant Mol Biol 51:21-37. https://doi.org/10.1023/A:1020780022549

Francesca N, Alfonzo A, Lo Verde G, Settanni L, Sinacori M, Lucido P, Moschetti G (2014) Biological activity of Bacillus spp. evaluated on eggs and larvae of red palm weevil Rhynchophorus ferrugineus. Ann Microbiol 65:477-485. https://doi.org/10.1007/ s13213-014-0881-4

Gao QM, Venugopal S, Navarre D, Kachroo A (2011) Low oleic acidderived repression of jasmonic acid-inducible defense responses requires the WRKY50 and WRKY51 proteins. Plant Physiol 155:464-476. https://doi.org/10.1104/pp.110.166876

Giovino A, Bertolini E, Fileccia V, Al Hassan M, Labra M, Martinelli F (2015) Transcriptome analysis of Phoenix canariensis Chabaud in response to Rhynchophorus ferrugineus Olivier attacks. Front Plant Sci 6:817. https://doi.org/10.3389/fpls.2015.00817

Giovino A, Martinelli F, Saia S (2016) Rhynchophorus ferrugineus attack affects a group of compounds rather than rearranging Phoenix canariensis metabolic pathways. J Integr Plant Biol 58:388396. https://doi.org/10.1111/jipb.12430

Guarino S, Lo Bue P, Peri E, Colazza S (2011) Responses of Rhynchophorus ferrugineus adults to selected synthetic palm esters: electroantennographic studies and trap catches in an urban environment. Pest Manag Sci 67:77-81. https://doi.org/10.1002/ps.2035

Guarino S, Peri E, Lo Bue P, Germanà MP, Colazza S, Anshelevich L, Ravid U, Soroker V (2013) Assessment of synthetic chemicals for disruption of Rhynchophorus ferrugineus response to attractantbaited traps in an urban environment. Phytoparasitica 41:79-88. https://doi.org/10.1007/s12600-012-0266-9

Guarino S, Colazza S, Peri E, Lo Bue P, Germanà MP, Kuznetsova T, Gindin G, Soroker V (2015) Behaviour-modifying compounds for management of the red palm weevil (Rhynchophorus ferrugineus Oliver). Pest Manag Sci 71:1605-1610. https://doi.org/10.1002/ ps.3966

Guillaumie S, Mzid R, Mechin V, Leon C, Hichri S, Destrac-Ivine A, Trossat-Magnin C, Delrot S, Lauvergeat V (2010) The grapevine transcription factor WRKY2 influences the lignin pathway and xylem development into tobacco. Plant Mol Biol 72:215-234. https://doi.org/10.1007/s11103-009-9563-1

Jaques JA, Riolo P, Audsley N, Barroso JM, Dembilio O, Isidoro N, Minuz RL, Nardi S, Navarro- Llopis V, Beaudoin-Ollivier L, 
QuesadaMoraga E (2017) Control Measures Against Rhynchophorus ferrugineus and Paysandisia archon. In: Soroker V, Colazza S (eds) Handbook of major palm pests: biology and management. Wiley, Hoboken, pp 255-279

Jones JDG, Dangl JL (2006) The plant immune system. Nature 444:323-329. https://doi.org/10.1038/nature05286

Kang K, Park S, Natsagdorj U, Kim YS, Back K (2011) Methanol is an endogenous elicitor molecule for the synthesis of tryptophan and tryptophan-derived secondary metabolites upon senescence of detached rice leaves. Plant J 66:247-257. https://doi.org/10.1111/ j.1365-313X.2011.04486.x

Kontodimas D, Soroker V, Pontikakos C, Suma P, Beaudoin-Ollivier L, Karamaouna F, Riolo P (2017) Visual identification and characterization of Rhynchophorus ferrugineus and Paysandisia archon. In: Soroker V, Colazza S (eds) Handbook of major palm pests: biology and management. Wiley, Hoboken, pp 187-208

Lo Verde G, La Mantia G, Griffo R (2011) El estado de la infestación por Rhynchophorus ferrugineus (Olivier) en Italia y los resultados de las pruebas de cirugía arbórea para el control de palmeras infestadas. Phytoma España 226:85-88

Lo Verde G, Torta L, Mondello V, Caldarella CG, Burruano S, Caleca V (2014) Pathogenicicty bioassays of isolates of Beauveria bassiana on Rhynchophorus ferrugineus. Pest Manag Sci 71:323-328. https://doi.org/10.1002/ps.385

Martinelli F, Reagan RL, Uratsu SL, Phu ML, Albrecht U, Zhao W, Davis C, Bowman KD, Dandekar AM (2013) Gene regulatory networks elucidating Huanglongbing disease mechanisms. PLoS ONE 8(9):e74256. https://doi.org/10.1371/journal.pone.0074256

Martinelli F, Dolan D, Fileccia V, Reagan RL, Phu M, Spann TM, McCollum TG, Dandekar AM (2016) Molecular responses to small regulating molecules against Huanglongbing disease. PLoS ONE 11(7):e0159610. https://doi.org/10.1371/journal.pone.01596 10

Martínez-Rach M, Migallón Gomis H, López Granado O, Perez Malumbres M, Martí Campoy A, Serrano Martín JJ (2013) On the design of a Bioacoustic sensor for the early detection of the Red Palm Weevil. Sensors 13:1706-1729. https://doi.org/10.3390/ s130201706

Mayer AM, Staples RC (2002) Laccase: new functions for an old enzyme. Phytochemistry 60: $551-65$. https://doi.org/10.1016/ S0031-9422(02)00171-1

Mzid R, Marchive C, Blancard D, Deluc L, Barrieu F, Corio-Costet MF, Drira N, Hamdi S, Lauvergeat V (2007) Overexpression of $V v W R K Y 2$ in tobacco enhances broad resistance to necrotrophic fungal pathogens. Physiol Plant 131:434-447. https://doi.org/10. 1111/j.1399-3054.2007.00975.x

Nakash J, Osem Y, Kehat M (2000) A Suggestion to Use Dogs for Detecting Red Palm Weevil (Rhynchophorus ferrugineus) Infestation in Date Palms in Israel. Phytoparasitica 28:153-155. https:// doi.org/10.1007/BF02981745

Pasini C, Rumine P (2014) Il Punteruolo rosso delle palme Rhynchophorus ferrugineus (Olivier): biologia, dannosità e linee di difesa. Italus Hortus 21(2):49-65

Rochat D, Dembilio O, Jaques JA, Suma P, La Pergola A, Hamidi R, Kontodimas D, Soroker V (2017) Rhynchophorus ferrugineus: taxonomy, distribution, biology, and life cycle. In: Soroker V, Colazza S (eds) Handbook of major palm pests: biology and management. Wiley, Hoboken, pp 69-104
Ross J, Li Y, Lim E, Bowles DJ (2001) Higher plant glycosyltransferases. Genome Biol 2: reviews3004.1-3004.6

Rushton PJ, Somssich IE, Ringler P, Shen QJ (2010) WRKY transcription factors. Trends Plant Sci 15:247-258. https://doi. org/10.1016/j.tplants.2010.02.006

SAS Institute (2008) SAS/STAT9.2. User's Guide. SAS Institute Inc, Cary

Soroker V, Suma P, La Pergola A, Llopis VN, Vacas S, Cohen Y, Cohen Y, Alchanatis V, Milonas P, Golomb O, Goldshtein E (2017) Surveillance techniques and detection methods for Rhynchophorus ferrugineus and Paysandisia archon. In: Soroker V, Colazza S (eds) Handbook of major palm pests: biology and management. Wiley, Hoboken, pp 209-232

Spoel SH, Koornneef A, Claessens SMC, Korzelius JP, Van Pelt JA, Mueller MJ, Buchala AJ, Métraux JP, Brown R, Kazan K, Van Loon LC, Dong X, Pieterse CMJ (2003) NPR1 modulates crosstalk between salicylate- and jasmonate-dependent defense pathways through a novel function in the cytosol. Plant Cell 15:760 - 770. https://doi.org/10.1105/tpc.009159

Suma P, La Pergola A, Longo A, Soroker V (2013) The use of sniffing dogs for the detection of Rhynchophorus ferrugineus. Phytoparasitica 42:269-274. https://doi.org/10.1007/s12600-013-0330-0

Suma P, Peri E, La Pergola A, Soroker V, Dembilio O, Riolo P, Nardi S (2017) Action Programs for Rhynchophorus ferrugineus and Paysandisia archon. In: Soroker V, Colazza S (eds) Handbook of major palm pests: biology and management. Wiley, Hoboken, pp 280-299

Vacas S, Melita O, Michaelakis A, Milonas P, Minuz R, Riolo P, Abbass MK, Lo Bue P, Colazza S, Peri E, Soroker V, Livne Y, Primo J, Navarro-Llopis V (2017) Lures for red palm weevil trapping systems: aggregation pheromone and synthetic kairomone. Pest Manag Sci 73:223-231. https://doi.org/10.1002/ps.4289

Vierstra RD (2003) The ubiquitin/26S proteasome pathway, the complex last. the life of many plant proteins. Trends Plant Sci 8:135142. https://doi.org/10.1016/S1360-1385(03)00014-1

Vogt T, Jones P (2000) Glycosyltransferases in plant natural product synthesis: characterization of a supergene family. Trends Plant Sci 5:380-386. https://doi.org/10.1016/S1360-1385(00)01720-9

Wu L, Zhong G, Wang J, Li X, Song X, Yang Y (2011) Arabidopsis WRKY28 transcription factor is required for resistance to necrotrophic pathogen, Botrytis cinerea. Afr J Microbiol Res 5:54815488. https://doi.org/10.5897/AJMR11.781

Xie Z, Zhang ZL, Zou X, Yang G, Komatsu S, Shen QJ (2006) Interactions of two abscisic-acid induced WRKY genes in repressing gibberellin signaling in aleurone cells. Plant J 46:231-242. https ://doi.org/10.1111/j.1365-313X.2006.02694.X

Yan C, Fan M, Yang M, Zhao J, Zhang W, Su Y, Xiao L, Deng H, Xie D (2018) Injury activates $\mathrm{Ca}^{2+} /$ Calmodulin-dependent phosphorylation of JAV1-JAZ8-WRKY51 complex for jasmonate biosynthesis. Mol Cell 70(1):136-149. https://doi.org/10.1016/j.molce 1.2018 .03 .013

Zhang ZL, Xie Z, Zou X, Casaretto J, Ho TH, Shen QJ (2004) A rice WRKY gene encodes a transcriptional repressor of the gibberellin signaling pathway in aleurone cells. Plant Physiol 134::15001513. https://doi.org/10.1104/pp.103.034967 